Sains Malaysiana 49(4)(2020): 721-728

http://dx.doi.org/10.17576/jsm-2020-4904-01

\title{
Perbandingan Ciri Anatomi Daun Tetrastigma rafflesiae (Miq.) Planchon dan Tetrastigma pedunculare (Wall. ex Laws.) Planch. di Semenanjung Malaysia
} (Comparative Leaf Anatomy of Tetrastigma rafflesiae (Miq.) Planchon and Tetrastigma pedunculare (Wall. ex Laws.) Planch. in Peninsular Malaysia)

\author{
Syamsurina Arshad*, Mohd Afiq Aizat Juhari, Noraini talip, Nor AzIlah Abdul Wahab, Syuhada \\ FADZILAH \& JUMAAT ADAM
}

\begin{abstract}
ABSTRAK
Kajian ini bertujuan untuk melakukan kajian terhadap ciri anatomi daun Tetrastigma rafflesiae (Miq.) Planchon dan Tetrastigma pedunculare (Wall. ex Laws.) Planch. yang merupakan perumah kepada bunga pakma dan pakma tikus di Semenanjung Malaysia. Sampel daun diperoleh daripada habitat asal iaitu Gunung Bubu, Gerik, Perak. Teknik piawai dalam anatomi tumbuhan digunakan dan imbasan adalah menggunakan mikroskop cahaya dan mikroskrop imbasan elektron (SEM) dengan pemerhatian dilakukan meliputi bahagian petiol, tulang daun, lamina, epidermis dan peruratan daun. Hasil menunjukkan kehadiran trikom dan sel arenkima hanya terdapat pada T. pedunculare sahaja. Bilangan berkas vaskular medula pada T. rafflesiae adalah tunggal, manakala T. pedunculare adalah tiga. Oleh itu, ketiga-tiga ciri ini dapat membezakan dengan jelas kedua-dua spesies.
\end{abstract}

Kata kunci: Anatomi daun; perumah; Tetrastigma pedunculare; Tetrastigma rafflesiae

\section{ABSTRACT}

This study aimed to study the leaf anatomy of Tetrastigma rafflesiae (Miq.) Planchon and Tetrastigma pedunculare (Wall. ex Laws.) Planch., the host of Rafflesia and Rhizanthes in Peninsular Malaysia. Leaf samples were collected in their natural habitat at Gunung Bubu, Gerik, Perak. Standard techniques in plant anatomy were employed, including analyses under light and scanning electron microscopy (SEM) with observation on the petioles, midrib, laminae, leaf epidermis and also on the leaf venation. The results show the presence of trichome and arenchyma cell only at $\mathrm{T}$. pedunculare. The number of medullary vascular bundle of $\mathrm{T}$. rafflesiae is only single but $\mathrm{T}$. pedunculare are three. Therefore, the three characteristic can be used to differentiate these two species.

Keywords: Host plants; leaf anatomy; Tetrastigma pedunculare; Tetrastigma rafflesiae

\section{PENDAHULUAN}

Tetrastigma (Miq.) Planch. ialah salah satu daripada genus dalam Vitaceae yang terdiri daripada 95 spesies serta tersebar luas di kawasan tropika Asia dengan lokaliti taburannya tersebar dari India ke China mengunjur sehingga ke Asia Tenggara dan ke arah timur hingga Fiji dengan beberapa spesies mengunjur ke Australia dan di Malesia (Kochaiphat et al. 2013; 2016; Latiff 2015, 1983; Wen et al. 2013). Genus ini amat terkenal di Asia Tenggara kerana ia merupakan satu-satunya perumah kepada bunga terbesar di dunia iaitu spesies holoparasit Rafflesiaceae (Febriyanti et al. 2013; Jamili 2004, 2001; Jumaat et al. 2016, 2013; Latiff 2015, 1983; Veldkamp 2007; Wen 2007; Wen, et al. 2013).
Tetrastigma rafflesiae juga dikenali dengan nama anggur liar, akar papan, akar cabang lima, kangkong gajah (Tan 2006), akar engkarana (Wan Nuur Fatiha et al. 2016) dan lipoi (Muhammad et al. 2014). Spesies ini merupakan liana yang boleh memanjat sehingga menjangkau ketinggian 15 meter, berkayu (Latiff 1983; Wan Nuur Fatiha et al. 2016) dan tidak dapat berdiri tegak dengan sendirinya untuk sebarang ketinggian serta memerlukan kepada bantuan pokok tinggi yang lain sebagai sokongan bagi mendapatkan cahaya matahari di bawah lindungan kanopi hutan (Akhriadi et al. 2010).

Tetrastigma pedunculare (Wall. ex Laws.) Planch. pula ialah perumah kepada Rhizanthes di Semenanjung Malaysia (Banziger 1995). Dikenali sebagai akar ulu, akar 
engkarang, akar ruran, wur siri, bakuh ruru, akar luran, benindu, poompoos, dan ulur-ulur (Latiff 2015) dan akar vita (Diway \& Chai 2004). Spesies ini mudah dikenal pasti di dalam hutan berdasarkan kepada morfologi batangnya yang berbentuk bulat, berwarna kelabu cerah hingga ke coklat cair dan mempunyai banyak akar udara yang mengunjur daripada kanopi hutan hingga ke lantai hutan dengan panjangnya yang mampu mencapai $20 \mathrm{~m}$ dan kebiasaannya mudah ditemui di tebing sungai (Banzinger 1995).

Tinjauan kepustakaan yang dilakukan mendapati bahawa kajian anatomi daun bagi kedua-dua spesies ini belum pernah dilakukan. Kajian yang relatif berkaitan dengan anatomi daun Tetrastigma di Malaysia pernah dilakukan oleh Chnar et al. (2013) pada spesies $T$. cruciatum, manakala pada $T$. hookeri oleh Nasihah et al. (2016). Oleh itu, hasil kajian ini diharapkan akan dapat membantu untuk kaedah pengecaman alternatif dan menyediakan maklumat sistematik tambahan bagi kedua-dua spesies perumah ini dengan menggunakan ciri anatomi daun.

\section{BAHAN DAN KAEDAH}

Sampel daun bagi $T$. rafflesiae dan $T$. pedunculare telah diperoleh dari Gunung Bubu, Gerik secara kerja lapangan seterusnya dijadikan spesimen baucar (Jadual 1). Kaedah dan teknik digunakan dalam penyediaan anatomi mengikut kaedah oleh Johansen (1940) dan Sass (1958) dengan pengubahsuaian meliputi kajian epidermis (Jadual 2), penjernihan tisu (Jadual 3), hirisan menggunakan mikrotom gelongsor, cerapan di bawah mikroskop cahaya dan mikroskop imbasan elektron (SEM) serta teknik-teknik yang berkaitan dengannya. Sebanyak tiga hingga empat replikasi dilakukan untuk kajian ini bagi memastikan kemalaran ciri anatomi pada spesies kajian.

JADUAL 1. Spesimen baucer untuk kajian anatomi daun

\begin{tabular}{lccl}
\hline Spesies & Kod dan tarikh kutipan & Lokaliti & \multicolumn{1}{c}{ Pengumpul } \\
\hline Tetrastigma & SBA0299/2015 & Gunung Bubu, & Syamsurina, Nor \\
rafflesiae & 10.10 .2015 & Grik, Perak & $\begin{array}{l}\text { Azilah \& Mohd Afiq } \\
\text { Aizat }\end{array}$ \\
& & & \\
Tetrastigma & SBA0190/2015 & Gunung Bubu, & Syuhada, Jumaat \& \\
pedunculare & 8.8 .2015 & Grik, Perak & Syamsurina \\
\hline
\end{tabular}

JADUAL 2. Langkah-langkah kajian epidermis

\begin{tabular}{|c|c|c|c|}
\hline Langkah & Larutan/Bahan pelekap & Masa & Catatan \\
\hline \multicolumn{4}{|l|}{ Pewarnaan } \\
\hline 1 & $\begin{array}{l}\text { 2-3 titik Safranin dititis ke dalam piring } \\
\text { petri yang mengandungi air dan tisu } \\
\text { hirisan }\end{array}$ & 5 minit & - \\
\hline 2 & $\begin{array}{l}\text { Tisu hirisan dicuci dengan air suling. } \\
\text { Proses ini diulangi tiga (3) kali }\end{array}$ & - & - \\
\hline 3 & $\begin{array}{l}\text { 2-3 titik Alcian green dititis ke dalam } \\
\text { piring petri yang mengandungi air dan } \\
\text { tisu hirisan }\end{array}$ & 5 minit & - \\
\hline 4 & $\begin{array}{l}\text { Tisu hirisan dicuci dengan air suling. } \\
\text { Proses ini diulangi tiga (3) kali }\end{array}$ & - & - \\
\hline \multicolumn{4}{|l|}{ Penyahairan } \\
\hline 1 & Alkohol $50 \%$ & 5 minit & Piring petri ditutup \\
\hline 2 & $\begin{array}{l}\text { Alkohol } 70 \%+\text { Beberapa titik larutan } \\
\text { asid hidroklorik (HCL) pekat }\end{array}$ & 2 minit & $\begin{array}{l}\text { Piring petri ditutup } \\
\text { dan digoncang } \\
\text { perlahan-lahan }\end{array}$ \\
\hline 3 & Alkohol $95 \%$ & 5 minit & Piring petri ditutup \\
\hline 4 & Alkohol $100 \%$ & 5 minit & Piring petri ditutup \\
\hline Perlekapan & Pelekap Euparal & & \\
\hline Pengeringan & - & 2 minggu & $\begin{array}{l}\text { Sisip kaca } \\
\text { dimasukkan } \\
\text { kedalam ketuhar } \\
\text { pada suhu } 60{ }^{\circ} \mathrm{C} /\end{array}$ \\
\hline
\end{tabular}


JADUAL 3. Langkah-langkah penjernihan tisu

\begin{tabular}{|c|c|c|c|}
\hline Langkah & Larutan/Bahan pelekap & Masa & Catatan \\
\hline \multicolumn{4}{|l|}{ Penyahairan } \\
\hline 1 & Alkohol $50 \%$ & 5 minit & Piring petri ditutup \\
\hline 2 & $\begin{array}{l}\text { Alkohol } 70 \%+\text { Beberapa titik larutan } \\
\text { asid hidroklorik }(\mathrm{HCL}) \text { peka }\end{array}$ & 2 minit & $\begin{array}{l}\text { Piring petri ditutup dan } \\
\text { digoncang perlahan-lahan }\end{array}$ \\
\hline 3 & Alkohol $95 \%$ & 5 minit & Piring petri ditutup \\
\hline 4 & Alkohol $100 \%$ & 5 minit & Piring petri ditutup \\
\hline 5 & Alkohol $100 \%+$ Xilen & & Piring petri ditutup \\
\hline 6 & Xilen & & $\begin{array}{l}\text { Piring petri ditutup, perlu } \\
\text { segera dilakukan kerana } \\
\text { boleh mengakibatkan tisu } \\
\text { hirisan menjadi kecut dan } \\
\text { rosak }\end{array}$ \\
\hline Perlekapan & Pelekap Canada balsam & & \\
\hline Pengeringan & - & 2 minggu & $\begin{array}{l}\text { Sisip kaca dimasukkan } \\
\text { kedalam ketuhar pada } \\
\text { suhu } 60^{\circ} \mathrm{C}\end{array}$ \\
\hline
\end{tabular}

\section{HASIL DAN PERBINCANGAN}

\section{KERATAN RENTAS PETIOL}

Pada keratan kentas petiol, T. rafflesiae mempunyai permukaan abaksial berbentuk $3 / 4$ bulatan dan adaksial sedikit cembung. Terdapat unjuran berbentuk cuping membulat hadir pada kiri dan kanan kawasan pertemuan bahagian adaksial dan abaksial (Rajah 1A) manakala T. pedunculare mempunyai permukaan abaksial berbentuk-U dan adaksial berbentuk cembung serta terdapat unjuran berbentuk cuping dengan bentuk kon hadir pada kiri dan kanan kawasan pertemuan bahagian adaksial dan abaksial (Rajah 1B). Menurut kajian yang dilakukan oleh Chnar et al. (2011), T. cruciatum, permukaan abaksial berbentuk -O dan adaksial berbentuk cembung. Pada T. hookeri pula didapati mempunyai permukaan abaksial berbentuk-U tidak seragam dan adaksial berbentuk cembung dengan unjuran berbentuk cuping hadir pada kiri dan kanan kawasan pertemuan bahagian adaksial dan abaksial (Nasihah et al. 2016). Justeru, didapati bentuk petiol adalah adalah berbeza mengikut varieti spesies tersebut.

Seterusnya, T. rafflesiae mempunyai satu lapisan sel epidermis (nisbah tinggi: lebar, 1:2) tanpa kehadiran trikom. Manakala T. pedunculare mempunyai lapisan sel epidermis (nisbah tinggi: lebar, 1:3) dengan kehadiran trikom ringkas (unisel). Trikom merujuk kepada unjuran unisel atau multisel yang terhasil daripada sel epidermis dan mengunjur keluar daripada permukaan organ tumbuhan (Amalia et al. 2013). Menurut Metcalfe dan Chalk (1957), trikom pada tumbuhan terdiri daripada jenis unisel, uniseriat, jambak atau stelat jarang. Kehadiran trikom ini dapat membezakan dengan jelas kedua-dua spesies ini dan kenyataan ini disokong oleh Morais et al. (2011) yang menyatakan kehadiran atau ketiadaan trikom dalam spesies boleh menjadi ciri diagnostik yang digunakan untuk pengecaman dan untuk membezakan sesuatu spesies.

Kehadiran sel arenkima dicerap hanya hadir pada bahagian parenkima korteks $T$. pedunculare iaitu pada bahagian adaksial petiol. Sel arenkima merujuk kepada rangkaian sel tumbuhan yang berhubungan dengan udara dalam menyediakan ruang untuk tumbuhan untuk menyerap oksigen di bawah keadaan hipoksik (Kacprzyk et al. 2011). Pembentukan sel ini merupakan penyesuaian kepada ciri anatomi bagi membolehkan tumbuhan beradaptasi pada keadaan persekitaran yang kekurangan air (Takahashi et al. 2014), mengurangkan halangan dalaman untuk mengangkut gas oksigen, nitrogen, unsur metabolik (karbon dioksida dan etilena terutamanya di antara akar dan pucuk) serta meningkatkan mekanisme kehilangan metana daripada sedimen berudara yang dibebaskan melalui tumbuhan ke atmosfera (Jackson \& Amstrong 1999). Menurut kajian morfologi yang dilakukan oleh Banziger (1995), T. pedunculare menghasilkan banyak akar udara. T. pedunculare yang matang akan terputus hubungannya dengan akar utama daripada lantai hutan dan hanya berhubung dengan akar udara yang tumbuh melepasi beberapa silara pokok besar. Keadaan morfologi ini telah menyokong kehadiran dan pembentukan sel arenkima pada T. pedunculare.

Seterusnya, kedua-dua spesies mempunyai tisu vaskular yang terdiri daripada sistem tertutup dengan satu gegelang. Pada T. rafflesiae didapati 19-20 berkas vaskular tersusun secara tidak selanjar bentuk-O berlekuk pada bahagian adaksial manakala pada $T$. pedunculare terdapat 18-19 berkas vaskular tersusun secara tidak selanjar bentuk-O. Merujuk kepada kajian terdahulu pada famili Vitaceae, terdapat (15-19) berkas vaskular pada 
T. hookeri (Nasihah et al. 2016), V. vinifera cv. Kshmsh (23-37 berkas vaskular), V. vinifera $c v$. Trespi (32-43), $V$. vinifera $c v$. Taefi (19-33), V. vinifera $c v$. Pasirani (2026), $V$. vinifera $c v$. Baesola (25-39) dan $V$. vinifera $c v$. Deselanz (16-25) (Chnar et al. 2011). Perbezaan bilangan berkas vaskular pada tumbuhan ini didapati berasosiasi mengikut spesies tumbuhan tersebut kerana sistem vaskular tumbuhan menjalankan dua fungsi penting iaitu sebagai penghantar sumber (air, mineral penting nutrien, gula dan asid amino) kepada seluruh organ tumbuhan dan dalam menyediakan sokongan mekanikal pada tumbuhan (Baucher et al. 2007; Lucas et al. 2013; Ye 2002).

Seterusnya, kedua-dua spesies didapati mempunyai bahagian empulur yang hadir dengan saiz yang besar secara relatifnya. Empulur terdiri daripada sel parenkima berspan dan terletak di bahagian tengah serta berfungsi dalam penyimpanan nutrien (Kirkendall et al. 2015).

Drus didapati hadir padat pada parenkima korteks, bawah lapisan sel epidermis, pada lapisan sel sklerenkima dan juga pada tisu vaskular tetapi kurang padat pada kawasan empulur. Sel musilaj pula dicerap hadir pada sel parenkima korteks. Menurut kajian yang dilakukan oleh Chnar (2014), drus juga direkodkan hadir pada famili Vitaceae yang dikaji manakala Solihani (2010) turut menemui drus di dalam tisu parenkima pada lamina, tulang daun dan petiol pada genus Mallotus Lour. (Euphorbiaceae) yang mempunyai perkaitan yang rapat dengan famili Vitaceae.

\section{KERATAN RENTAS TULANG ANAK DAUN}

Permukaan adaksial berbonggol, permukaan abaksial bentuk-U dengan dasar rata merupakan bentuk luaran tulang anak daun bagi $T$. rafflesiae (Rajah 1C) manakala T. pedunculare mempunyai permukaan adaksial berbentuk kon dan permukaan abaksial bentuk hampir segi empat (Rajah 1D). Kedua-dua spesies mempunyai tisu vaskular dengan sistem tertutup dan terdiri daripada satu gegelang tisu vaskular yang terdiri daripada beberapa berkas vaskular (7-9 berkas vaskular) pada T. rafflesiae dan (9-15 berkas vaskular) pada $T$. pedunculare yang secara amnya tersusun secara tidak selanjar bentuk-O. Namun begitu, berkas vaskular medula pada $T$. rafflesiae adalah tunggal, manakala $T$. pedunculare adalah tiga. Kedua-dua spesies juga menunjukkan kehadiran sel dan salur musilaj pada parenkima korteks, serta kehadiran sel musilaj terhasil daripada bahagian dalam idoblas. Peningkatan bilangan sel ini menyebabkan tekanan pada dinding sel. Kesan tekanan ini seterusnya mengakibatkan penyingkiran hablur kristal keluar daripada dinding sel (Olivera et al. 2012). Justeru itu, kajian ini turut menemui hablur drus padat hadir pada parenkima korteks, pada kawasan medulari terutama sekali pada bahagian berdekatan tisu vaskular.

\section{KERATAN RENTAS TULANG ANAK DAUN}

Tetrastigma pedunculare menunjukkan kehadiran trikom pada epidermis abaksial daun. Hanya T. pedunculare dilaporkan menunjukkan kehadiran trikom manakala spesies Tetrastigma lain seperti T. hookeri (Nasihah et al. 2016), T. dichotomum, $T$. diepenhorstii dan $T$. megacarpum (Nur Aishah 2016) tidak menunjukkan kehadiran trikom. Kedua-dua spesies diperhatikan menunjukkan kedudukan berkas vaskular berada di tengah-tengah di antara epidermis abaksial dan epidermis abaksial yang terletak relatif sangat berjauhan antara satu sama lain (Rajah 1E \& 1F). Berkas vaskular utama dan sekunder terdiri daripada berkas vaskular ringkas mendatar. Selain itu, hablur jenis drus hadir di dalam sel idioblas pada mesofil palisad. Mesofil span didapati turut hadir pada kedua-dua spesies kajian ini.

\section{EPIDERMIS ANAK DAUN}

Kedua-dua spesies mempunyai dinding antiklin epidermis adaksial dan abaksial lurus ke melengkung (Rajah $1 \mathrm{G}$ \& 1H). Pada kambium aktif tumbuhan, terdapat dua kaedah pembahagian mitotik iaitu pembahagian periklin (dinding sel baharu bersudut melintang dari permukaan epidermis luar) dan pembahagian antiklin (dinding sel baharu bersudut tegak dari permukaan epidermis luar) (Beck 2010). Dinding antiklin epidermis mempunyai pelbagai bentuk iaitu bentuk lurus, melengkung atau sinuat. Pada tumbuhan monokotiledon dan dikotiledon, dinding antiklin epidermis didapati adalah sangat nipis dan sukar dilihat dengan mata kasar (Cutler et al. 2007). Kehadiran kepelbagaian sel kambium ini amat penting dalam tumbuhan kerana ia mempengaruhi mekanisme pemanjangan sel (Angyalossy et al. 2012).

Menurut al-Edany et al. (2011) serta Noraini dan Cutler (2009), jenis ornamentasi yang terdapat pada stomata menjadi ciri diagnostik dan mempunyai peranan yang signifikan untuk proses pengecaman sesuatu spesies. Stomata berperanan penting dalam mengawal pergerakan air dalam tumbuhan (Cutler et al. 2007). Pemerhatian mendapati kedua-dua spesies ini mempunyai ciri stomata homostomatik dan hipostomatik dari jenis diasitik serta dicerap hadir hanya pada permukaan epidermis abaksial sahaja. Tetrastigma rafflesiae mempunyai saiz stomata 28-30 $\mu \mathrm{m}$ manakala $T$. pedunculare 26-28 $\mu \mathrm{m}$. Stomata bersaiz kurang daripada $15 \mu \mathrm{m}$ dikelaskan sebagai 'kecil' manakala saiz melebihi $38 \mu \mathrm{m}$ dikategorikan sebagai 'besar' (Saadu et al. 2009). Indeks stomata pada direkodkan pada $T$. rafflesiae adalah $45.16 \%$ manakala T. pedunculare $(28.57 \%)$. Perbezaan indeks ini merujuk kepada corak dan ruang yang terdapat pada stomata dan ia bergantung sepenuhnya kepada saiz sel serta saiz dan bentuk ruang udara di dalamnya (Glover 2000). 

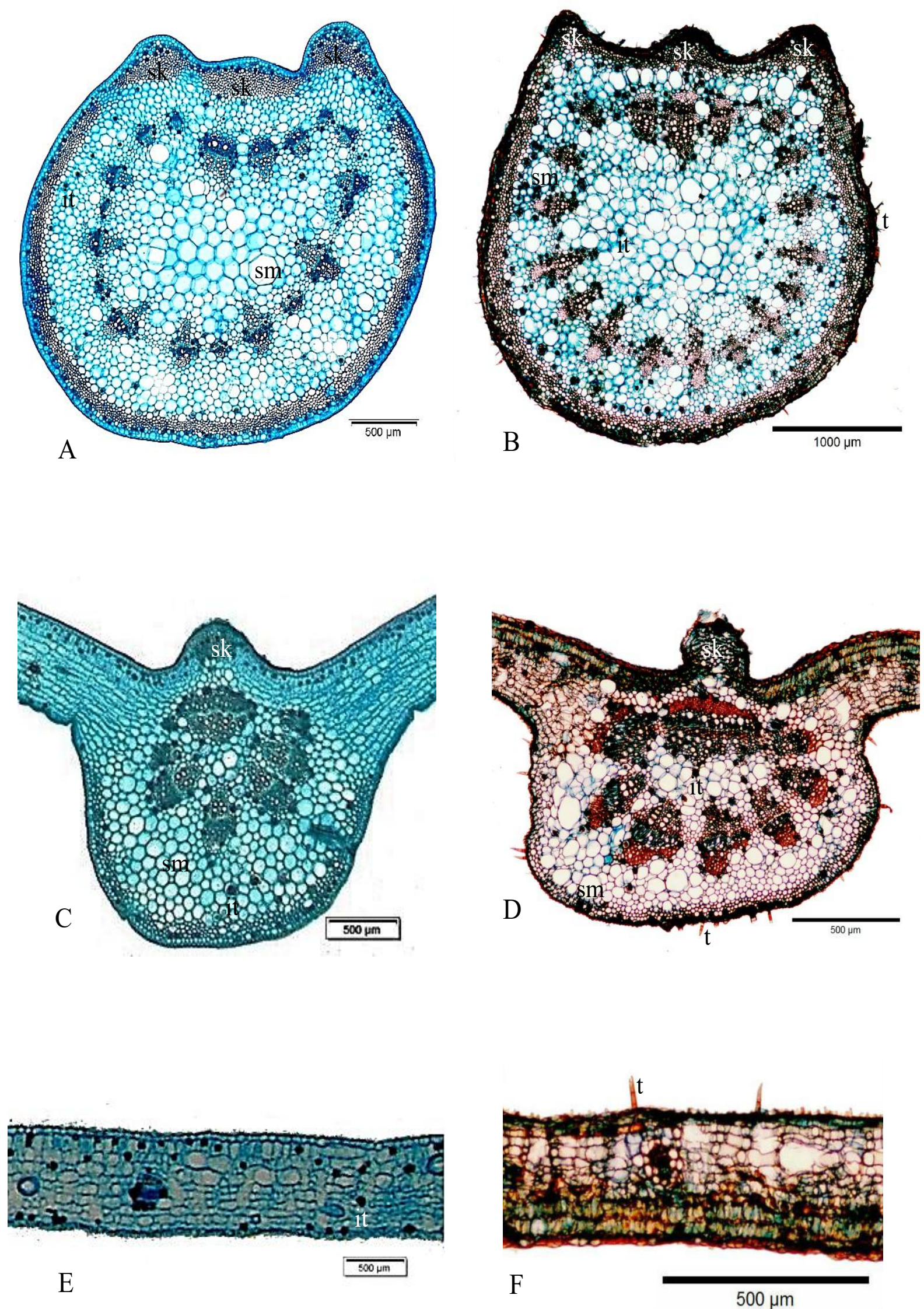

E

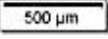

RAJAH 1. Tetrastigma rafflesiae (A, C \& E); Tetrastigma pedunculare (C, D \& F): A \& B) KR Petiol; C \& D) KR Tulang daun; E \& F) KR Lamina daun, [sk: sel kolenkima, sm: salur musilaj, it: idobias tanin, t: trikom](c) RCTL, (d) ERAic, and (e) ERAbc 

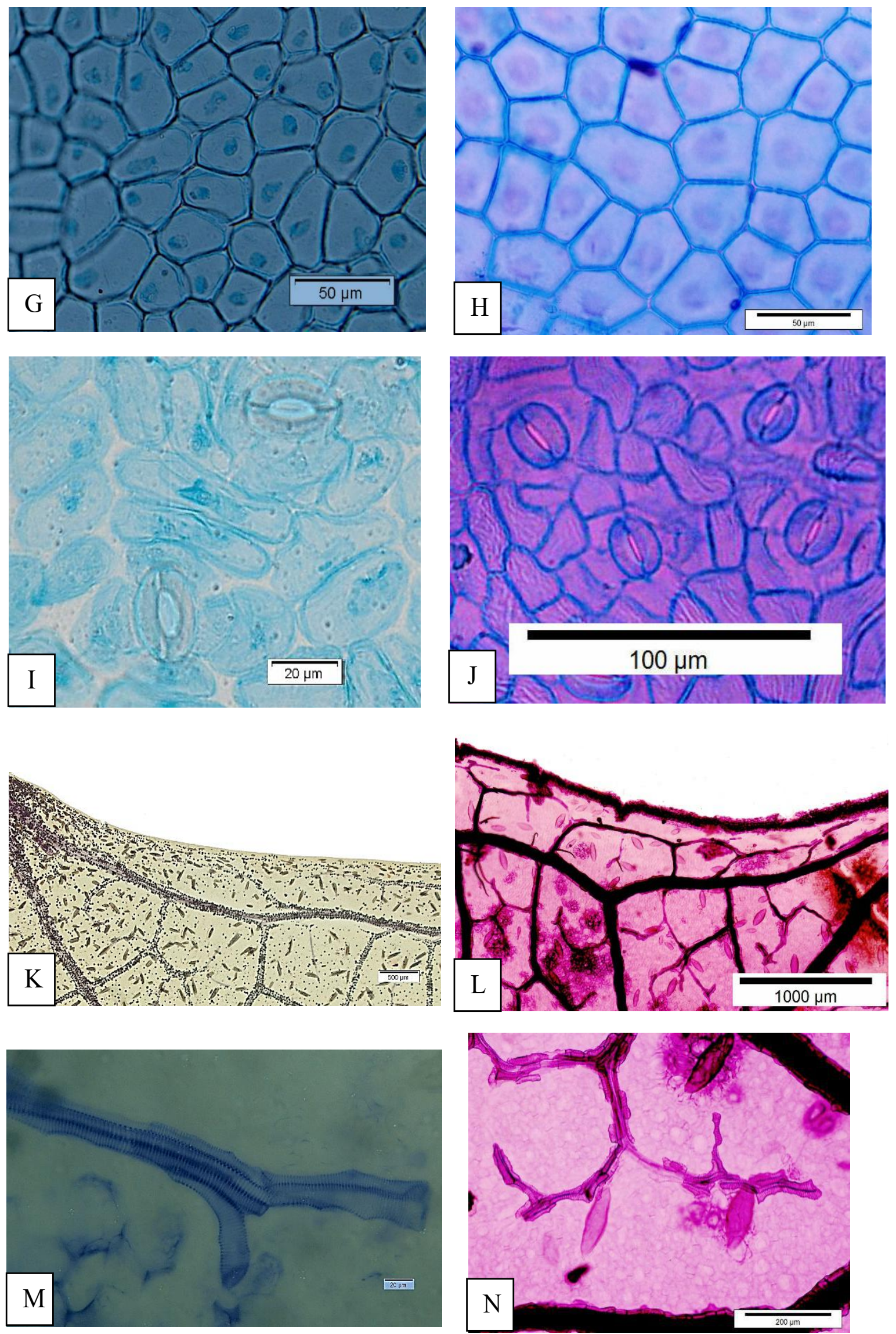

RAJAH 2. Tetrastigma rafflesiae (G, I, K \& M); Tetrastigma pedunculare (H, J, L \& N); G \& H - Permukaan epidermis adaksial; I \& J - Permukaan epidermis abaksial; K \& L - Peruratan margin daun; M \& N - Trakeid 


\section{PERURATAN ANAK DAUN}

Kedua-dua spesies mempunyai peruratan tepi tidak lengkap, peruratan tengah dengan majoriti tertutup dan minoriti terbuka dengan hujung bebas dan bercabang dua atau tunggal (Rajah 1K \& 1L) serta trakeid bengkak (Rajah $1 \mathrm{M} \& 1 \mathrm{~N})$. Conklin et al. (2019) menyatakan hampir keseluruhan daun tumbuhan dikotiledon mempunyai peruratan tengah dengan majoritinya berbentuk struktur jaring anastomos. Hormon auksin yang terdapat pada tumbuhan (Kumar \& Kellogg 2019) dan faktor biotik dan abiotik (Klein et al. 2017) mempengaruhi jenis peruratan pada sesuatu tumbuhan. Ciri-ciri yang terdapat pada peruratan daun juga amat penting dalam menentukan kadar pertukaran gas dan perkembangan sesuatu jenis tumbuhan tersebut (Sack et al. 2013).

\section{KESIMPULAN}

Hasil kajian menunjukkan T. rafflesiae dan T. pedunculare boleh dibezakan dengan jelas melalui kehadiran trikom, sel arenkima dan juga berkas vaskular medula. Ketigatiga ciri ini amat penting dalam kajian anatomi daun bagi kedua-dua spesies yang dikaji khasnya dalam membantu membezakan perumah kepada Rafflesia dan Rhizanthes khususnya di Malaysia. Oleh itu, adalah diharapkan kajian ini dapat menjadi panduan untuk kajian seterusnya pada masa hadapan.

\section{PENGHARGAAN}

Penulis mengucapkan setinggi-tinggi penghargaan kepada kakitangan di Makmal Mikroteknik, UKM dan Makmal Histologi, Institut Agro-Bioteknologi Malaysia, MARDI. Penghargaan kepada geran penyelidikan FRGS/1/2014/ ST03/UKM/01/1 kerana membiayai kajian ini.

\section{RUJUKAN}

Akhriadi, P., Kiswanto, H.A., Taufiq, A., Alfajri, D. \& Kardiman, R. 2010. Assessment of conservation status of Rafflesia in West Sumatra, Indonesia. Laporan akhir kepada dana kecil Rufford (untuk pemuliharaan semula jadi). Pasukan pemantau Rafflesia (RMT) Padang, Indonesia.

Al-Edany, T.Y., Sahar, A. \& Al-Saadi, A.M. 2011. Taxonomic significance of anatomical characters in some species of the family Myrtaceae. American Journal of Plant Sciences 3: 572-581.

Amalia, R., Noraini, T., Jalifah, L., Ruzi, A.R. \& Idris, S. 2013. Morphology of trichomes in Pogostemon cablin Benth. (Lamiaceae). Australia Journal of Crop Science 7(6): 744749.

Angyalossy, V., Angeles, G., Pacea, M.R., Lima, A.C., DiasLeme, C.L., Lohmann, L.G. \& Madero-Vega, C. 2012. An overview of the anatomy, development and evolution of the vascular system of lianas. Plant Ecology and Diversity 5(2): 167-182.

Banziger, H. 1995. Ecological, morphological and taxonomic studies on Thailand's fifth species of Rafflesiaceae: Rhizanthes zippelli (Blume) Spach. Natural History Bulletin of the Siam Society 43: 337-365.
Baucher, M., El-Jaziri, M. \& Vandeputte, O. 2007. From primary to secondary growth: Origin and development of the vascular system. Journal of Experimental Botany 58(13): 3485-3501.

Beck, C.B. 2010. An Introduction to Plant Structure and Development Plant Anatomy for the Twenty-First Century. Edisi ke-2. Edinburgh: Cambridge University Press.

Chnar, N. 2014. Leaf anatomy and palynological differences among selected cultivars of Vitis vinifera and Parthenocissus quinquefolia (Vitaceae). The International Weekly Journal for Species 9(21): 6-12.

Chnar, N., Khatijah, H. \& Haja, M. 2013. Comparative leaf anatomy of selected species in Vitaceae and Leeaceae. American Journal of Applied Sciences 10(4): 414-417.

Chnar, N., Khatijah, H. \& Haja, M. 2011. Comparative study on the anatomy and palynology of the three variety of Vitis vinifera varity (family Vitaceae). African Journal of Biotechnology 10(74): 16866-16874.

Cutler, D.F., Botha, T. \& Stevenson, D.W. 2007. Plant Anatomy: An Applied Approach. New York: Blackwell Publishing Ltd.

Conklin, P.A., Strable, J., Li, S. \& Scanlon, M.J. 2019. On the mechanisms of development in monocot and eudicot leaves. New Phytologist 221: 706-724.

Diway, B.M. \& Chai, P.P.K. 2004. Development of Lanjak Entimau Wildlife Sanctuary as a totally protected area. A study on the vegetation of Batang Ai National Park, Sarawak Malaysia. International Tropical Timber Organization (ITTO), Forestry Department Sarawak Malaysia.

Febriyanti, E., Suwirmen \& Idris, M. 2013. Induksi perakaran tunas Tetrastigma rafflesiae Miq. pada media Murashigeskoog dengan penambahan beberapa konsentrasi indole-3butyric acid (IBA) secara in vitro. Jurnal Biologi Universitas Andalas 2(2): 161-167.

Glover, B.J. 2000. Differentiation in plant epidermal cells. Journal of Experimental Botany 51(344): 497-205.

Jackson, M.B. \& Amstrong, W. 1999. Formation of aerenchyma and the processes of plant ventilation in relation to soil flooding and submergence. Plant Biology 1(3): 274-287.

Jamili, N. 2004. Rafflesia Bunga Terbesar di Dunia. Kota Kinabalu: Natural History Publication.

Jamili, N. 2001. Rafflesia of the World. Kota Kinabalu: Penerbit Sabah Parks.

Johansen, D.A. 1940. Plant Microtechnique. New York: McGrawHill Book Company Inc.

Jumaat, H.A., Mohd Afiq Aizat, J., Rahmah, M., Nor Azilah, A.W., Syamsurina, A., Mohd Paiz, K., Mohd Firdaus, M.R. \& Kiew-Lian, W. 2016. Rafflesia tuanku-halimii (Rafflesiaceae), a new species from Peninsular Malaysia. Sains Malaysiana 45(11): 1589-1595.

Jumaat, H.A., Rahmah, M., Mohd Afiq Aizat, J., Nik Nadira Farhana, N.A. \& Kiew-Lian, W. 2013. Rafflesia sharifahhapsahiae (Rafflesiaceae), a new species from Peninsular Malaysia. Turkish Journal of Botany 37: 1038-1044.

Kacprzyk, J., Daly, C.T. \& McCabe, P.F. 2011. The botanical dance of death: Programmed cell death in plants. Advance in Botanical Research Journal 60: 169-261.

Kirkendall, L.R., Biedermann, P.H.W. \& Jordal, B.H. 2015. Evolution and diversity of bark and ambrosia beetles. Chapter 3. Dlm. Bark Beetles: Biology and Ecology of Native and Invesive Species, disunting oleh Vega, F.E. \& Hofstetter, R.W. London: Academic Press. hlm. 85-156.

Kochaiphat, P., Trias-Blasi, A. \& Pornpongrungrueng, P. 2016. Two new species of Tetrastigma (Miq.) Planch. (Vitaceae) 
from Thailand. European Journal of Taxonomy 201: 1-12.

Kochaiphat, P., Trias-Blasi, A. \& Pornpongrungrueng, P. 2013. Comparative leaves anatomy of some Cayratia Juss and Tetrastigma (Miq.) Planch. in Thailand. Proceedings of the 29th National Graduate Research Conference, Mae Fah Luang University, Chiang Rai, Thailand. hlm. 883-891.

Klein, L.L., Caito, M., Chapnick, C., Kitchen, C., O'Hanlon, R., Chitwood, D.H. \& Miller, A.J. 2017. Digital morphometrics of two North American grapevines (Vitis:Vitaceae) quantifies leaf variation between species, within species, and among individuals. Frontiers in Plant Science 8(373): 1-10.

Kumar, D. \& Kellogg, E.A. 2019. Getting closer: Vein density in C4 leaves. New Phytologist 221: 1260-1267.

Latiff, A. 2015. Studies in Malesian Vitaceae XV. Revision of Tetrastigma (Miq.) Planch. sect. Carinata Latiff. Malayan Nature Journal 67(3): 318-327.

Latiff, A. 1983. Studies in Malesian Vitaceae VII. The genus Tetrastigma in the Malay Peninsula. Gardens Bulletin of Singapore 36(2): 213-228.

Lucas, W.J., Groover, A., Lichtenberger, R., Furuta, K., Yadav, S.R., Helariutta, Y., He, Q., Fukuda, H., Kang, J., Brady, S.M., Patrick, J.W., Sperry, J., Yoshida, A., Mill, A.F.L., Grusak, M.A. \& Kachroo, P. 2013. The plant vascular system: Evolution, development and functions. Journal of Integrative Plant Biology 55(4): 294-388.

Metcafe, C.R. \& Chalk, L. 1957. Anatomy of the Dicotyledons. Oxford: Clarendon Press.

Morais, T.M.D.S., Rabelo, G.R., Alexandrino, C.R., Neto, S.J.D.S. \& Cunha, M.D. 2011. Comparative leaf anatomy and micromorphology of Psychotria species (Rubiaceae) from the Atlantic Rainforest. Acta Botanica Brasilica 25(1): 178-190.

Muhammad, A.Z., Nor, S.O., Zaini, Y., Mohd Lias, K. \& Jamil, T. 2014. Identification of alkaloid compound and antioxidant activity of Rafflesia cantleyi and its host, Tetrastigma tuberculatum. The Open Conference Proceedings Journal 5: $18-20$.

Nasihah, M., Zulhazman, H., Siti Munirah, M.Y., Wan Norqayyum Nadia, W.A. \& Latiff, A. 2016. Tetrastigma hookeri (Laws.) Planch. (Vitaceae), a host plant for Rafflesia kerrii Meijer in Peninsular Malaysia. Malayan Nature Journal 68(1\&2): 33-39.

Noraini, T. \& Cutler, D.F. 2009. Leaf anatomical and micromorphological characters of some Malaysian Parashorea (Dipterocarpaceae). Journal of Tropical Forest Science 21(2): 156-167.

Nur Aishah, A. 2016. Comparative leaf anatomy of Tetrastigma species (Vitaceae) from Gunung Mulu National Park, Sarawak. Tesis Sarjana Muda. Universiti Malaysia Sarawak (tidak diterbitkan).

Olivera, A.B., Mendonça, M.S., Azevedo, A.A. \& Meira, R.M.S.A. 2012. Anatomy and histochemistry of the vegetative organs of Cissus verticillata - A native medicinal plant of the Brazilian Amazon. Brazilian Journal of Pharmacognosy 22(6): 1201-1211.
Saadu, R.O., Abdulrahaman, A.A. \& Oladele, F.A. 2009. Stomatal complex types and transpiration rates in some tropical tuber species. African Journal of Plant Science 3(5): 107-112.

Sack, L., Scoffoni, C., John, G.P., Poorter, H., Mason, C.M., Mendez-Alonzo, R. \& Donovan, L.A. 2013. How do leaf veins influence the worldwide leaf economic spectrum? Review and synthesis. Journal of Experimental Botany 64(13): 4053-4080.

Sass, J.E. 1958. Botanical Microtechnique. Edisi ke-3. Ames: Iowa State University Press.

Solihani, S.N., Noraini, T., Ruzi, A.R \& Chung, R.C.K. 2010. Nilai taksonomi ciri anatomi daun Coelostegia Benth. dan Ceiba pentandra Gaertn. (Bombacaceae). Sains Malaysiana 39(3): 371-376.

Takahashi, H., Yamauchi, T., Colmer, T.D. \& Nakazono, M. 2014. Aerenchyma formation in plants. In Low Oxygen Stress in Horticulture Practise, edited by van Dongen, J.T. \& Licausi, F. Springer: Vienna. hlm. 247-265.

Tan, A.L. 2006. Kajian Rafflesia Kuala Melantai Pahang. Tesis Sarjana Muda, Universiti Kebangsaan Malaysia (tidak diterbitkan).

Veldkamp, J.F. 2007. The correct name for the Tetrastigma (Vitaceae) host of Rafflesia (Rafflesiaceae) in Malesia and a (not so) new species. Reinwardtia 12(4): 261- 265.

Wan Nuur Fatihah, W.Z., Aida Shafreena, A.P., Geri, C., Ramlah, Z. \& Latiff, A. 2016. Tetrastigma diepenhorstii (Miq.) Latiff (Vitaceae), a new host of Rafflesia tuan-mudae Becc. (Rafflesiaceae) in Borneo. Journal of Botany 2016: 3952323.

Wen, J. 2007. Vitaceae. Dlm. The Families and Genera of Vascular Plants Volume IX Flowering Plants Eudicots, disunting oleh Kubitzki, K. Berlin: Springer-Verlag. hlm. 467-479.

Wen, J., Lu, L. \& Boggan, J.K. 2013. Diversity and evolution of Vitaceae in the Philippines. Philippine Journal of Science Special Issue 142: 223-244.

Ye, Z.H. 2002. Vascular tissue differentiation and pattern formation in plants. Annual Review of Plant Biology 53: 183-202.

Pusat Pengajian Sains Sekitaran dan Sumber Alam

Fakulti Sains dan Teknologi

Universiti Kebangsaan Malaysia

43650 UKM Bangi, Selangor Darul Ehsan

Malaysia

*Pengarang untuk surat-menyurat; email: p70780@siswa.ukm. edu.my

Diserahkan: 18 September 2018

Diterima: 18 Disember 2019 